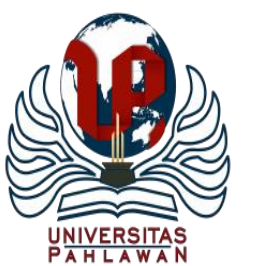

Jurnal Basicedu Volume 4 Nomor 4 Tahun 2020 Halm. 829 - 837

JURNAL BASICEDU

Research \& Learning in Elementary Education

https://jbasic.org/index.php/basicedu/index

\title{
Pengembangan Bahan Ajar Tematik Pada Keterampilan Menulis Berbasis Model Pembelajaran Kooperatif Tipe Round Table di Sekolah Dasar
}

\author{
Lylga Febrina ${ }^{1}$, Taufina ${ }^{2}$, Farida $\mathbf{F}^{3}$ \\ Universitas Negeri Padang, Sumatera Barat, Indonesia ${ }^{1,2,3}$ \\ E-mail: eghabharata@gmail.com ${ }^{1}$ taufina@ fip.unp.ac.id ${ }^{2} \underline{\text { Faridafachruddin67@gmail.com }}^{3}$
}

\begin{abstract}
Abstrak
Keterampilan menulis siswa pada saat ini sangat rendah. Hal ini diakibatkan karena bahan ajar yang digunakan guru dalam proses pembelajaran masih belum mencakup materi yang sesuai dengan indikator ketercapaian di dalam proses pembelajaran. Model pembelajaran yang digunakan juga belum terlihat sesuai dengan materi yang dijelaskan. Jenis penelitian ini adalah penelitian pengembangan dengan desain 4D dimana peneliti membuat sebuah bahan ajar sesuai dengan kebutuhan dan ketercapaian yang ditujukan oleh guru. Penelitian ini dilakukan di kelas IV SDN 18 Sitiung. Pada awal penelitian dilakukan observasi untuk melihat kondisi awal sebelum digunakan bahan ajar yang didesain guru dengan menggunakan model tipe round table. Model pembelajaran tipe round table menggunakan prinsip: 1) berpusat pada siswa, 2) mengembangkan kreativitas siswa, 3) menciptakan kondisi menyenangkan dan menantang, 4) bernilai, etika, estetika, logika, dan kinestika, dan 5) menyediakan pengalaman belajar yang beragam.
\end{abstract}

Kata kunci : bahan ajar, round table, keterampilan menulis

\begin{abstract}
Writing skills of students at this time are very low. This is caused because teaching materials used by teachers in the learning process still do not include material that is in accordance with indicators of achievement in the learning process. The learning model that is used also does not look in accordance with the material described. This type of research is a $4 D$ research development in which the researcher makes a teaching material in accordance with the needs and achievements addressed by the teacher. This research was conducted in class IV SDN 18 Sitiung. At the beginning of the study, observations were made to see the initial conditions before teaching materials were designed which the teacher designed using the round table type model. The round table type of learning model uses the following principles: 1) student-centered, 2) develops student creativity, 3) creates fun and challenging conditions, 4) values, ethics, aesthetics, logic, and kinesthetic, and 5) provides a diverse learning experience.
\end{abstract}

Keyword : material describe, round table, writing skills

Copyright (c) 2020 Lylga Febrina, Taufina, Farida F

Corresponding author :

Address :

Email : eghabharata@gmail.com

ISSN 2580-3735(Media Cetak)

Phone :

ISSN 2580-1147(Media Online)

DOI: 10.31004/basicedu.v4i4.438 
830 Pengembangan Bahan Ajar Tematik Pada Keterampilan Menulis Berbasis Model Pembelajaran Kooperatif Tipe Round Table di Sekolah Dasar- Lylga Febrina, Taufina, Farida F DOI: 10.31004/basicedu.v4i4.438

\section{PENDAHULUAN}

Bahan ajar merupakan segala bentuk yang digunakan untuk membantu guru dalam melaksanakan kegiatan belajar mengajar. Sagala (2009: 23) menjelaskan salah satu kompetensi profesionalisme yang harus dimiliki guru adalah mampu menyusun bahan ajar yang berkualitas sesuai dengan kompetensi, kompetensi dasar, dan bahan ajar yang sesuai dengan kebutuhan dan karakteristik peserta didik. Depdiknas (2008:6) menjelaskan bahan ajar berfungsi sebagai (1) pedoman bagi guru yang akan mengarahkan semua aktivitasnya dalam proses pembelajaran, sekaligus sebagai substansi kompetensi yang harus diajarkan kepada peserta didik, (2) pedoman bagi peserta didik yang akan mengarahkan semua aktivitasnya dalam proses pembelajaran dan merupakan substansi kompetensi yang harus dikuasai, dan (3) sebagai alat evaluasi pencapaian hasil pembelajaran. Menurut pendapat (Weriyanti, Firman dan Taufina 2020 : 477) bahan ajar yang kurang sesuai dengan kriteria, maka akan timbul berbagai permasalahan dalam proses pembelajaran.

Menurut pendapat Ceríaco (dalam Taufina, 2020) sejumlah sekolah, beberapa masalah di antaranya membutuhkan analisis. Pertama, guru sekolah dasar membutuhkan bahan ajar yang sesuai dengan perkembangan siswa. Kedua, bahan ajar untuk pemahaman membaca yang dilakukan di kelas kurang memberikan perhatian pada teknik pemahaman membaca. Dengan demikian, menemukan siswa yang tidak menerapkan teknik membaca pemahaman. Ketiga, materi yang diajarkan jarang menggunakan cerita rakyat sebagai media pembelajaran yang tidak berdaya untuk meningkatkan sikap siswa terhadap karakter positif. Keempat, kualitas teks dalam pemahaman bacaan dipengaruhi oleh ketersediaan gambar. Kelima, masih ada karakter negatif sebagai siswa dari kesalahan formulir aplikasi di media tontonan. Mengatasinya perlu untuk mengembangkan bahan ajar untuk membaca menggunakan cerita rakyat secara efektif, kreatif, dan fokus.

Menurut pendapat (Ahmadi dan Amri, 2014:83) "metode tematik integratif adalah pembelajaran yang menggunakan tema dalam mengaitkan beberapa materi ajar sehingga dapat memberikan pengalaman bermakna pada peserta didik". Kemudian Mamik (dalam Mulyoto, 2013:118) menjelaskan bahwa "pembelajaran tematik adalah pembelajaran yang mengintegrasikan materi beberapa pelajaran dalam satu tema pembahasan".

Menurut pendapat ahli di atas dapat disimpulkan bahwa pembelajaran tematik merupakan pembelajaran yang mengaitkan beberapa mata pelajaran dan kompetensi dalam bentuk tema dimana peserta didik mendapatkan pengalaman bermakna dalam proses pembelajaran tersebut.

Tematik disajikan dalam bentuk tema bukan dalam bentuk mata pelajaran, tema inilah yang mengintegrasikan seluruh mata pelajaran. Dimana dalam hal ini Bahasa Indonesia berperan sebagai pengikat antar-mata pelajaran yang diintegrasikan. Pembelajaran tematik integratif pada kurikulum 2013 memiliki beberapa karakteristik. Menurut Majid (2014:126) ada beberapa karaketristik pembelajaran tematik integratif yaitu: "1) berpusat pada peserta didik, 2) memberikan pengalaman langsung, 3) pemisahan mata pelajaran tidak begitu 
831 Pengembangan Bahan Ajar Tematik Pada Keterampilan Menulis Berbasis Model Pembelajaran Kooperatif Tipe Round Table di Sekolah Dasar- Lylga Febrina, Taufina, Farida F DOI: 10.31004/basicedu.v4i4.438

jelas, 4) menyajikan konsep dari berbagai mata pelajaran, 5) bersifat fleksibel, dan 7) menggunakan prinsip belajar“. Saat ini masih banyak terjadi di lapangan proses pembelajaran tematik yang dimaksud belum terlaksana dengan baik. Masih banyak guru-guru tersebut menggunakan gaya lama yang menjadikan dirinya sebagai penceramah yang baik. Sehingga karakteristik pembelajaran tematik masih belum tercapai secara maksimal dalam kurikulum 2013.

Kenyataan yang terjadi di lapangan guru masih sebagai sumber utama dalam proses pembelajaran dan belum maksimal menjadikan pembelajaran berpusat pada peserta didik sehingga apa yang didapatkan oleh peserta didik selama pembelajaran bukan dari pengalamannya melainkan hanya melalui proses mencawan apa saja yang diberikan guru. Pemisahan mata pelajaran terlihat jelas bahkan guru menyebutkan mata pelajaran yang dimaksud hal ini terjadi karena adanya penekanan dari pengawas kecamatan yang menyampaikan bahwa mata pelajaran disebutkan. Kemudian guru hanya mengandalkan penggunaan buku-buku pelajaran tanpa menganalisa terlebih dahulu apakah buku tersebut sesuai dengan kompetensi dasar yang harus dikuasai peserta didik. Kreativitas maupun pemahaman guru terhadap perancangan bahan ajar pun masih kurang, ini terlihat ketika mengajar guru tidak membuat bahan ajar sendiri. Jika dilihat dari kelayakan isi dan penyajian, bahan ajar yang digunakan guru belum cukup sesuai dengan pembelajaran tematik dan belum memasukkan proses tahapan menulis pada keterampilan menulis pada bidang studi bahasa indonesia.
Proses pembelajaran yang terjadi di lapangan pada kegiatan menulis di kelas tinggi tidak melaksanakan sesuai dengan tahap-tahap proses menulis. Kegiatan menulis hanya diisi dengan kegiatan tanpa bimbingan dari guru. Guru tidak mengarahkan, dan hanya memberikan kebebasan yang tak terbatas kepada peserta didik. Kemudian hasil dari tulisan siswa hanya dilihat secara umum saja tanpa memperhatikan penggunaan ejaan dan tidak melakukan perbaikan-perbaikan yang seharusnya dilakukan. Sehingga peserta didik tidak mengetahui dimana letak kesalahannya dan pada akhirnya pencapaian yang harus dicapai dalam keterampilan menulis jauh dari ketercapaian. Apalagi saat ini telah berlakunya kurikulum 2013 yang menerapkan aspek pengetahuan, aspek keterampilan, dan aspek sikap. Dimana proses pembelajarannya dengan tematik yang mengitegrasikan materi pembelajaran dalam satu tema pembahasan. Dengan demikian peserta didik dituntut tidak hanya memahami suatu konsep saja namun peserta didik diharapkan mampu mengembangkan keterampilan yang dimilikinya untuk dikembangkan misalnya dalam mengembangkan keterampilan menulis pada Bahasa Indonesia.

Menurut Taufina (2016: 69) tahap-tahap dalam proses menulis ada tiga yaitu pramenulis, saat menulis, dan pasca menulis (merevisi, mengedit, dan menyajikan). Pramenulis merupakan tahap persiapan. Pada tahap ini seorang penulis melakukan berbagai kegiatan, misalnya menemukan ide gagasan, menentukan judul karangan, menentukan judul, memilih bentuk atau jenis tulisan, membuat kerangka, dan mengumpulkan bahan-bahan. Ide 
832 Pengembangan Bahan Ajar Tematik Pada Keterampilan Menulis Berbasis Model Pembelajaran Kooperatif Tipe Round Table di Sekolah Dasar- Lylga Febrina, Taufina, Farida F DOI: 10.31004/basicedu.v4i4.438

tulisan dapat dapat bersumber dari pengalaman, observasi, bahan bacaan, dan imajinasi. Oleh karena itu, pada ide atau gagasan. Kegiatan ini dapat dilakukan melalui berbagai aktivitas, misalnya membaca buku, surat kabar, majalah, dan sejenisnya, menyimak warta berita, pidato, khotbah, diskusi, dan seminar, karya wisata dan rekreasi dan sebagainya. Saat menulis tahap penulisan dimulai dengan menjabarkan ide ke dalam bentuk tulisan. Ide-ide itu dituangkan dalam bentuk kalimat dan paragraf. Selanjutnya, paragraf-paragraf itu dirangkaikan menjadi satu karangan yang utuh. Tahap ini memerlukan berbagai pengetahuan kebahasaan dan teknik penulisan. Pengetahuan kebahasaan digunakan untuk pemilihan kata, penentuan gaya bahasa, pembentukan kalimat, sedangkan teknik penulisan untuk penyusunan paragraf sampai dengan penyusunan karangan secara utuh. Pasca menulis terdiri atas, yaitu: merevisi atau mengubah. Pada tahap merevisi dilakukan koreksi terhadap keseluruhan karangan.

Koreksi dilakukan terhadap berbagai aspek, misalnya struktur karangan. Koreksi terhadap berbagai aspek, misalnya struktur karangan dan kebahasaan. Struktur karangan meliputi penataan ide pokok dan ide penjelasan, serta sistematika dan penalarannya. Sementara itu, aspek keabsahan meliputi pilihan kata, struktur bahasa, ejaan, dan tanda baca. Pada tahap revisi masih dimungkinkan mengubah judul karangan apabila judul yang telah ditentukan dirasakan kurang tepat. Mengedit, apabila karangan sudah dianggap sempurna, penulis tinggal melaksanakan tahap pengeditan. Dalam pengeditan ini diperlukan format buku yang kan menjadi acuan, misalnya ukuran kertas, bentuk tulisan, dan pengaturan spasi. Proses pengeditan dapat diperluas dan disempurnakan dengan penyediaan gambar atau ilustrasi. Hal itu dimaksudkan agar tulisan itu lebih mudah dipahami dan menarik. Gambar dan ilustrasi untuk melengkapi tulisan yang dikomunikasikan untuk anak-anak sebaiknya berwarna. Menyajikan atau mempublikasikan tulisan, mempublikasikan tulisan mempunyai dua pengertian. Pengertian pertama, berarti menyampaikan karangan kepada publik dalam bentuk cetakan, sedangkan pengertian kedua menyampaikan karangan tidak dalam bentuk cetakan. Penyampaian tanpa cetakan dapat dilakukan dengan pementasan, perceritaan, peragaan, dan sebagainya. Karangan berbentuk cerita anak-anak misalnya dapat disampaikan melalui majalah. Secara sederhana, karangan semacam itu memiliki dampak psikologi yang amat baik. Pemajangan hasil karya anak-anak dapat berfungsi ganda, di samping untuk penguatan juga dapat memacu semangat bersaing secara positif.

Menurut Hartig (dalam Taufina 2016:231) mengungkapkan bahwa tujuan menulis adalah: assignment purpose (tujuan penugasan). Penulis tidak memiliki tujuan, untuk apa ia menulis. Penulis hanya menulis, tanpa mengetahui tujuannya. Ia menulis karena mendapat tugas, bukan karena kemauan sendiri. Misalnya siswa ditugaskan merangkum sebuah buku atau seorang guru disuruh membuat laporan oleh kepala sekolahnya. Kedua, altrutstic purpose (tujuan altruistik). Penulis bertujuan untuk menyenangkan para pembaca, menghindarkan kedukaan para pembaca, ingin menolong para pembaca memahami, menghargai perasaan dan penalarannya, ingin membuat hidup 
833 Pengembangan Bahan Ajar Tematik Pada Keterampilan Menulis Berbasis Model Pembelajaran Kooperatif Tipe Round Table di Sekolah Dasar- Lylga Febrina, Taufina, Farida F DOI: 10.31004/basicedu.v4i4.438

para pembaca lebih mudah dan menyenangkan dengan karya itu. Penulis harus berkeyakinan, bahwa pembaca adalah "teman hidupnya." Sehingga penulis benar-benar dapat mengkomunikasikan suatu ide atau gagasan bagi kepentingan pembaca. Hanya dengan cara itulah tujuan altruistik dapat tercapai. Ketiga, persuasive purpose (tujuan persuasif). Penulis bertujuan mempengaruhi pembaca, agar para pembaca yakin akan kebenaran gagasan atau ide yang dituangkan atau diutarakan oleh penulis. Tulisan semacam ini banyak dipergunakan oleh para penulis untuk menawarkan sebuah produksi barang dagangan, atau dalam kekuatan politik. Keempat, informational purpose (tujuan informasional, tujuan penerangan). Penulis menungkan ide/gagasan dengan tujuan memberi informasi atau keterangan kepada pembaca. Mengatasi masalah yang dikemukakan di atas, guru hendaknya mampu mengembangkan perangkat pembelajaran menulis secara efektif dan kreatif yang berorientasi pada model pembelajaran menulis yang tepat tanpa mengenyampingkan pelaksanakan pembelajaran sesuai dengan kurikulum yaitu pembalajaran tematik integratif. Pengembangan bahan ajar dilakukan dengan mempertimbangkan model pembelajaran yang sesuai agar tujuan yang diharapkan dapat tercapai. Salah satu model pembelajaran yang sesuai untuk pengembangan bahan ajar menulis adalah dengan menggunakan model pembelajaran kooperatif tipe round table.

Pembelajaran kooperatif menuntut peserta didik agar dapat bekerja dalam suatu kelompok yang terdiri dari tiga atau lebih anggota. Melalui pembelajaran kooperatif dapat memberikan manfaat, yaitu dapat meningkatkan cara belajar peserta didik dalam kesatuan kelompok yang bekerja sama sehingga terbentuk tingkah laku peserta didik dalam berkomunikasi dengan sesama temannya. Sugiyanto (2010:33) menyatakan bahwa "model kooperatif (cooperative learning) adalah pendekatan pembelajaran yang berfokus pada penggunaan kelompok kecil siswa untuk bekerja sama dalam memaksimalkan kondisi belajar untuk mencapai tujuan belajar". Pembelajaran kooperatif model round table dikembangkan dengan dasar pendekatan kooperatif dan kontekstual. Tulisan yang paling tepat untuk jenis ini adalah tulisan kreatif (cerpen, puisi, dan drama/dialog).

Model pembelajaran kooperatif round table ini dapat digunakan pada pembelajaran bahasa indonesia hal ini didukung menurut Lie (2000: 62) yang menyatakan bahwa pembelajaran kooperatif model round table dapat digunakan dalam semua mata pelajaran dan untuk semua tingkatan usia anak didik. Kagan (2009:6.34) menerangkan bahwa model pembelajaran kooperatif tipe round table adalah model pembelajaran yang menunjuk peserta didik dalam suatu kelompok bergiliran mengambil bagian untuk menulis tanggapan, memecahkan masalah, memberikan kontribusi dalam proyek". Menurut Mccafferty (2006:191) Kooperatif model round table merupakan teknik menulis yang menerapkan pembelajaran dengan menunjuk tiaptiap anggota kelompok untuk berpartisipasi secara bergiliran dalam kelompokknya dengan membentuk meja bundar atau duduk melingkar (Mccafferty, 2006: 191). Dengan model round table ini peserta didik dapat menuliskan ide yang dimilikinya tanpa merasa tertekan dan terbebani. Peserta didik menuangkan dalam bentuk tulisan yang mana 
834 Pengembangan Bahan Ajar Tematik Pada Keterampilan Menulis Berbasis Model Pembelajaran Kooperatif Tipe Round Table di Sekolah Dasar- Lylga Febrina, Taufina, Farida F DOI: 10.31004/basicedu.v4i4.438

mereka saling berlomba menyelesaikan tugasnya dengan enjoy namun tetap diberikan batas waktu oleh gurunya.

Model pembelajaran kooperatif tipe round table dapat mengiring peserta didik untuk mampu menulis dengan ejaan bahasa yang benar sehingga dapat mengembangkan kreativitas peserta didik. Sesuai dengan yang tercantum dalam Permendikbud Nomor 81 A Tahun 2013 pada lampiran menyatakan bahwa untuk mencapai kualitas yang telah dirancang dalam dokumen kurikulum, kegiatan pembelajaran perlu menggunakan prinsip yang: (1) berpusat pada peserta didik, (2) mengembangkan kreativitas peserta didik, (3) menciptakan kondisi menyenangkan dan menantang, (4) bermuatan nilai, etika, estetika, logika, dan kinestika, dan (5) menyediakan pengalaman belajar yang beragam melalui penerapan berbagai strategi dan metode pembelajaran yang menyenangkan, kontekstual, efektif, efisien, dan bermakna.

\section{METODE}

Jenis penelitian ini adalah pengembangan yang mengacu pada model 4-D, model ini dikembangkan oleh S. Thiagarajan, Dorothy S. Sammel, dan Melvyn I Sammel. Sugiyono (2009:404) menjelaskan tahap-tahap model 4-D antara lain: pendefinisian (define), perancangan (design), pengembangan (develop), dan penyebaran (disseminate).Akan tetapi, karena keterbatasan tenaga, biaya, dan waktu penulis, tahap penyebaran (disseminate) hanya dilakukan pada skala terbatas yaitu kelas IV Sekolah Dasar sesuai dengan kebutuhan penulis.
Pada tahap pertama, pendefinisian dilakukan analisis kurikulum, analisis kebutuhan serta analisis peserta didik. Tahap kedua, perancangan dilakukan perancangan bahan ajar sesuai dengan Kompetensi Inti (KI) dan Kompetensi Dasar (KD) serta kesesuaian materi dengan kurikulum yang berlaku, kemudian memilih sumber belajar, menentukan urutan proses pembelajaran sesuai dengan strategi pembelajaran kooperatif tipe round table serta tata bahasa yang digunakan. Tahap ketiga, pengembangan dilakukan validasi oleh validator sebagai ahli dalam memvalidasi bahan ajar yang telah dirancang, revisi jika perlu adanya perbaikan terhadap bahan ajar yang dirancang dan tahap uji coba produk atau bahan ajar setekah dilakukannya revisi yang disarankan oleh validator. Tahap uji coba ini juga bermanfaat untuk mengetahui praktikalitas dan efektifitas dari bahan ajar yang dirancang. Tahap keempat, yaitu penyebaran bahan ajar. Penyebaran dilakukan dikelas IV Sekolah Dasar (SD).

\section{HASIL DAN PEMBAHASAN}

Bahan ajar merupakan sebuah sumber materi pembelajaran yang digunakan guru pada saat proses pembelajaran untuk memfokuskan tujuan materi pembelajaran yang akan dibahas sesuai dengan indikator pembelajaran yang ingin dicapai oleh guru. Bahan ajar memiliki komponen-komponen tertentu yang saling terkait satu sama lain. Seperti yang diterangkan oleh Hamdani (2011:122) yaitu beberapa komponen yang terdapat pada suatu bahan ajar di antaranya: a) judul, mata pelajaran, standar kompetensi, kompetensi dasar, indikator, dan tujuan pembelajaran, b) petunjuk belajar (petunjuk siswa 
835 Pengembangan Bahan Ajar Tematik Pada Keterampilan Menulis Berbasis Model Pembelajaran Kooperatif Tipe Round Table di Sekolah Dasar- Lylga Febrina, Taufina, Farida F DOI: 10.31004/basicedu.v4i4.438

dan guru), berisi tentang penjelasan cara penggunaan suatu bahan ajar yang akan dipelajari dalam sebuah proses pembelajaran, c) informasi pendukung, d) lembar kerja, f) evaluasi.

Abdul (2006:174) juga mengemukakan "sebuah bahan ajar paling tidak mencakup antara lain: 1) Kompetensi yang akan dicapai, 2) petunjuk belajar (petunjuk guru dan siswa), informasi pendukung, dan evaluasi”. Sedangkan menurut Mujiyono (2014: 3) menjelaskan bahwa komponen bahan ajar terdiri atas (1) identitas mata pelajaran, meliputi judul, materi, kompetensi, indikator, tujuan (2) petunjuk belajar, meliputi petunjuk untuk peserta didik dan guru, (3) isi materi pembelajaran, (4) informasi pendukung, (5) latihan-latihan, lembar kerja, (6) penilaian, (7) respon/balikan/ refleksi.

Berdasarkan paparan di atas, bahan ajar memuat judul, mata pelajaran, kompetensi inti, kompetensi dasar, indikator, tujuan pembelajaran, petunjuk belajar (petunjuk guru dan peserta didik), berisi tentang penjelasan cara penggunaan suatu bahan ajar yang akan dipelajari dalam sebuah proses pembelajaran, informasi pendukung, lembar kerja, dan evaluasi. Bahan ajar yang digunakan oleh guru disesuaikan dengan kurikulum yang berlaku dimana kurikulum yang berlaku pada saat ini adalah kurikulum 2013.

Kurikulum 2013 adalah kurikulum dengan bentuk pembelajaran tematik integratif. Pembelajaran tematik integratif merupakan pembelajaran yang mengaitkan materi mata pelajaran dalam satu tema dalam satu kali pertemuan sehingga dapat memberikan pengalaman bermakna bagi peserta didik.
Menurut Sutirjo dan Sri Mamik dalam Iif Khoru Ahmadi dan Sofan Amri (2004:90) menyatakan bahwa "pembelajaran tematik integratif merupakan satu usaha pembelajaran, serta pemikiran yang kreatif dengan menggunakan tema”. Kemudian Iif Khoru Ahmadi dan Sofan Amri (2004:94) menjelaskan bahwa "pembelajaran tematik integratif adalah pembelajaran terpadu yang menggunakan tema untuk mengaitkan beberapa mata pelajaran sehingga dapat memberikan pengalaman bermakna kepada peserta didik". Sedangkan menurut Abdul Majid (2004:123) menyatakan bahwa "pembelajaran tematik integratif adalah pembelajaran integratif yang menggunakan tema sebagai pemersatu materi dalam beberapa mata pelajaran sekaligus dalam satu kali pertemuan".

Berdasarkan data yang ada dikelas IV SDN 18 Sitiung pada proses pembelajaran sebelum menggunakan bahan ajar tanpa menggunakan model dengan proses pembelajaran yang telah menggunakan bahan ajar yang dibuat secara mandiri oleh guru dengan menggunakan model round table efektif dalam mengembangkan keterampilan menulis siswa.

Ini terlihat dari hasil keterampilan menulis siswa yang sudah mampu menggunakan bahan ajar yang dibuat guru dengan model round table pada saat proses pembelajaran. Model pembelajaran ini dapat dirangkaikan pada bahan ajar pada keterampilan menulis khususnya menuliskan kembali teks nonfiksi ke dalam tulisan dengan bahasa sendiri. Idealnya bahan ajar yang digunakan oleh guru hendaknya sesuai dengan kebutuhan kurikulum dan tahapan menulis yaitu pramenulis, saat menulis, dan pasca menulis. Hal ini terbukti 
836 Pengembangan Bahan Ajar Tematik Pada Keterampilan Menulis Berbasis Model Pembelajaran Kooperatif Tipe Round Table di Sekolah Dasar- Lylga Febrina, Taufina, Farida F DOI: 10.31004/basicedu.v4i4.438

setelah penulis melakukan analisis buku guru dan buku siswa yang digunakan guru dalam proses pembelajaran. Buku yang tersedia belum memuat proses menulis secara keseluruhan dan pencapaian kompetensi menulis jauh dari maksimal ini terlihat dari buku guru Kurikulum 2013 kemendikbud revisi 2016 dari 8 indikator pembelajaran, hanya memuat 2 indikator pembelajaran. Sangat jauh dari standar buku yang diharpkan buku ini hanya memenuhi $25 \%$ pencapaian standar kompetensi menulis. Begitu pula buku tulis yang digunakan oleh buku siswa tidak jauh berbeda karena panduan lahirnya buku siswa dari buku guru tersebut. Buku guru pun hanya memuat 2 indikator pembelajaran dari. Buku ini hanya memenuhi $25 \%$ pencapaian standar kompetensi menulis. Pencapaian standar kompetensi menulis (dapat dilihat pada lampiran). Dapat disimpulkan bahwa buku guru dan buku siswa yang tersedia digunakan guru dan peserta didik di sekolah belum memaksimalkan keterampilan menulis peserta didik. Dari observasi yang dilakukan dapat disimpulkan bahwa RPP dan bahan ajar yang digunakan oleh oleh guru dalam pembelajaran membaca belum mendukung terciptanya aktivitas dari kompetensi menulis itu sendiri.

Berdasarkan beberapa jurnal yang penulis temukan ada yang serupa dalam pembuatan bahan ajar tematik di kelas IV yaitu Jurnal milik Fatikh Inayahtur Rahma Vol.13, No.1, April 2018 yang sama-sama mengkaji mengenai pengembangan bahan ajar tematik di kelas IV dimana produk pengembangan bahan ajar tematik berbasis karakter dengan multimedia interaktif, yakni produk yang dihasilkan berupa bahan ajar yang menggunakan multi media interaktif sedangkan penulis melakukan pengembangan bahan ajar tematik khusus pada keterampilan menulis dengan menggunakan model pembelajaran kooperatif tipe round table. Jurnal penelitian lainnya yang mendukung penulis untuk melakukan penelitian pengembangan adalah jurnal milik Ni Kadek Mika Yustika Dewi Volume 2, number 1 Tahun Terbit 2018, pp. 81-88, ini merupakan penelitian tindakan kelas yang meningkatkan kemampuan menulis melalui teknik round table, sama hal nya dengan penelitian yang penulis lakukan berfokus pada keterampilan menulis dengan teknik round table namun perbedaannya penelitian ini dilakukan di kelas XI Mipa sedangkan penulis meneliti untuk sekolah dasar kelas IV dengan pembelajaran tematik.

Pembelajaran kooperatif menuntut peserta didik agar dapat bekerja dalam suatu kelompok yang terdiri dari tiga atau lebih anggota. Melalui pembelajaran kooperatif dapat memberikan manfaat, yaitu dapat meningkatkan cara belajar peserta didik dalam kesatuan kelompok yang bekerja sama sehingga terbentuk tingkah laku peserta didik dalam berkomunikasi dengan sesama temannya. Sugiyanto (2010:33) menyatakan bahwa "model kooperatif (cooperative learning) adalah pendekatan pembelajaran yang berfokus pada penggunaan kelompok kecil siswa untuk bekerja sama dalam memaksimalkan kondisi belajar untuk mencapai tujuan belajar". Pembelajaran kooperatif model round table dikembangkan dengan dasar pendekatan kooperatif dan kontekstual. Tulisan yang paling tepat untuk jenis ini adalah tulisan kreatif (cerpen, puisi, dan drama/dialog). 
837 Pengembangan Bahan Ajar Tematik Pada Keterampilan Menulis Berbasis Model Pembelajaran Kooperatif Tipe Round Table di Sekolah Dasar- Lylga Febrina, Taufina, Farida F DOI: 10.31004/basicedu.v4i4.438

\section{KESIMPULAN}

Keterampilan menulis merupakan sebuah keterampilan yang harus dimiliki oleh siswa. Pada saat ini, keterampilan menulis siswa sangat rendah sehingga banyak siswa yang kurang mampu dalam menciptakan sebuah karya tulisan. Hal ini disebabkan karena kurangnya sumber materi ajar yang digunakan guru. Bahan ajar yang dibuat sendiri oleh guru dengan memperhatikan kebutuhan yang sesuai dengan materi pada proses pembelajaran tentu dapat menjadi sebuah solusi dalam meningkatnya keterampilan menulis siswa.

Selain dengan dibuatnya bahan ajar oleh guru, menambahkan model pembelajaran juga menunjang keterampilan menulis siswa. Salah satu bentuk model pembelajaran yang dapat digunakan yaitu model round table. Model round table ini adalah model pembelejaran dimana semua anggota kelompok harus memahamai materi yang diberikan guru melalui teman sekelompoknya. sehingga keterampilan menulis siswa lebih baik dan meningkat.

\section{DAFTAR PUSTAKA}

Ardipal musik, seni, di smp, dan negeri padang, "penerapan model cooperativ learning terhadap aktivitas belajar siswa di smp negeri 1 padang," 2013, 53-60

Abbas, S. (2006). Pembelajaran Bahasa Indonesia Yang Efektif Disekolah Dasar. Jakarta: Depdiknas.

Abdul Majid. 2006. Perencanaan Pembelajaran Mengembangkan Standar Kompetensi Guru. Bandung: PT Remaja Rosdakarya. Iman, M, M. (2014). Helping EFL students improve their writing. International Journal of Humanities and Social Science. Vol.4, No.2, 105-112.
Lif Khoiru Ahmadi \& Sofan Amri. Pengembangan $\&$ Model Pembelajaran Tematik Integratif.

Jakarta: Prestasi Pustaka.

Ni Kadek Mika Yustika Dewi. 2018. Meningkatkan Kemampuan Menulis Melalui

Teknik Roundtable Pada Siswa. Jear, Vol.2, No.1, Tahun 2018, pp 81-88.

Rizka Amelia Azizah, Suhartono, Warsiti (2015). Penggunaan Model Kooperatif Tipe Round Tabledengan Media Gmbar dalam peningkatan Keterampilan Menulis Cerita Pada Siswa Kelas IV SD Negeri Cisumur 04 Tahun Pelajaran 2014/205, Kalam Cendekia, Volume 3, Nomor 2.1, hlm. 154-159.

Sugiyono. 2012. Metode Penelitian Pendidikan. Bandung: Alfabeta

Taufina Taufik (2015). Studi Penerapan Pendekatan Tematik Terpadu Dalam Rangka Implementasi Kurikulum 2013 Di Sekolah Dasar Kabupaten Lima Puluh Kota. Vol 1. Tahun 2015.

Taufina Taufik (2015). Studi Penerapan Pendekatan Tematik Terpadu Dalam Rangka Implementasi Kurikulum 2013 Di Sekolah Dasar Kabupaten Lima Puluh Kota. Vol 1. Tahun 2015.

Taufinaa, Izzati, dan Muhammad Ilham Syarif (2020). Using Indonesia Folklore to Improve Good Attitudes in Elementary School Students. International Journal of Innovation, Creativity and Change. www.ijicc.netVolume 12, Issue 10,2020

Wina Sanjaya. 2013. Penelitian Pendidikan. Jakarta. Prenada Media Group.

Weriyanti, Firman, Taufina, Ahmad Zikri (2020). Pengembangan bahan ajar tematik terpadu dengan strategi question student have di sekolah dasar. Jurnal Basicedu Vol 4 No 2 April 2020 